\title{
Cancer Survivors' Greatest Challenges of Living with an Ostomy: Findings from the Ostomy Self- Management Telehealth (OSMT) Randomized Trial
}

Marcia Grant ( $\nabla$ marciagrant113@gmail.com )

City of Hope Comprehensive Cancer Center Duarte https://orcid.org/0000-0003-3611-3034

Virginia Sun

City of Hope Comprehensive Cancer Center Duarte

Nancy J. Tallman

Unaffiliated

Christopher S. Wendel

Arizona Center on Aging: The University of Arizona Center on Aging

Ruth McCorkle

Yale University

Elizabeth Ercolano

Yale University

Christie Simons

Unaffiliated

Julia Mo

University of Pennsylvania

Sabreen Raza

University of Pennsylvania

Deborah Donahue

Unaffiliated

Frank Passero

Unaffiliated

Joshua Henson

Unaffiliated

Lyn MacDougall

Unaffiliated

Jonathan Friedlaender

Unaffiliated

Pamela Pitcher

Unaffiliated

Dan Fry 
Unaffiliated

\section{Pete Yonsetto}

The University of Arizona

\section{Michael J. Holcomb}

The University of Arizona

\section{Mark C. Hornbrook}

Kaiser Permanente

\section{Ronald S. Weinstein}

The University of Arizona

\section{Robert S. Krouse}

University of Pennsylvania

\section{Research Article}

Keywords: Cancer Survivors, Ostomies, Challenges, Telehealth Support

Posted Date: April 22nd, 2021

DOl: https://doi.org/10.21203/rs.3.rs-296700/v1

License: (c) (7) This work is licensed under a Creative Commons Attribution 4.0 International License. Read Full License

Version of Record: A version of this preprint was published at Supportive Care in Cancer on August 26th, 2021. See the published version at https://doi.org/10.1007/s00520-021-06449-6. 


\section{Abstract}

Objectives

An ostomy results in lifelong quality of life changes for a cancer survivor. We describe the greatest challenges reported from a randomized trial of cancer survivors with stomas (ostomies).

Methods

Cancer survivors with ostomies participating in a multi-site randomized prospective trial of an Ostomy Self-Management Telehealth (OSMT) Program versus usual care (UC) were surveyed at six months post accrual. An open-ended question requested greatest challenges after ostomy surgery. Quantitative descriptive and qualitative analyses were used to examine greatest challenges reported.

Results

118 trial participants identified greatest challenges with 55 in the OSMT and 63 in the UC. Six conceptual domains were used to code comments - Physical, Psychological, Social and Spiritual Quality of Life; Ostomy Specific Issues, and Health Care Issues. The OSMT contributed 187 comments and UC contributed 235 comments. Ostomy Specific Issues and Social Well Being had the most comments overall with UC contributing more comments in all domains except Physical Well Being. Word Clouds revealed Post-Operative and Treatment Related Issues and Going Out in Public as the most common challenges in both groups. Word Clouds compared types of ostomies revealing Bowel Function challenges (colostomy group), Difficulties Going Out in Public (ileostomy group), and Positive Support (urostomy group).

Conclusions

Fewer challenges submitted by the OSMT group provides beginning evidence of the OSMT Program impact. Dominant challenges across both groups were Social Well Being and Ostomy Care. Challenges varied by type of ostomy. Findings support long term care and support for all cancer survivors with ostomies.

Trial Registration: NCT02974634

\section{Introduction}

Cancer survivors (CS) whose treatment includes creation of a stoma, either colostomy, urostomy or ileostomy, face challenges that can impact all aspects of quality of life (QOL) [1-4]. Approximately 725,000 to 1 million people in the United States have an ostomy [5]. While initial teaching of how to care for an ostomy occurs when survivors are still hospitalized following surgery, many problems become evident after discharge, when survivors are at home in their own environment and participating in the activities that are part of their usual daily life. 
Previous studies have described challenges faced by these cancer survivors. Challenges include taking care of the ostomy appliance and related skin care, dealing with personal feelings about the ostomy, managing to participate comfortably in social events, and managing personal and intimate relationships $[6,7]$. Results of these studies provided the foundation for development of a program on Ostomy SelfManagement [8]. A curriculum was developed and tested with survivors using a hospital outpatient, inperson approach [9]. One of the critiques of this initial program focused on the learning environment and the difficulties encountered in having to travel to the medical center for the classes. To address this problem, we developed a telehealth version of the curriculum - the Ostomy Self-Management Telehealth (OSMT) program (10). This program provided the previously tested curriculum, teaching and support to postoperative ostomy survivors at home via secure group videoconferencing. We tested this program in a randomized trial, comparing survivors assigned to the OSMT program and usual care (UC). This report describes survivors' self-reported greatest challenges with ostomy care by study arm (OSMT or usual UC) and by type of ostomy.

\section{Methods}

\section{Study Sample and Design}

The study protocol and procedures have been described elsewhere [10]. Briefly, the OSMT program was tested in a multi-site trial of 216 cancer survivors living with an ostomy and their support persons/family caregivers. The primary purpose of the study was to determine the efficacy of the OSMT program to improve patient activation, self-efficacy, activation, and quality of life in the adjustment to living with an ostomy. Participants were enrolled from the University of Pennsylvania (Philadelphia, PA), Yale University (New Haven, CT), and City of Hope (Duarte, CA). Protocol and procedures were approved by the Institutional Review Boards of all participating sites. Cancer survivors who were 21 years of age or older and at least six weeks after surgery that included the creation of a fecal or urinary stoma were enrolled and randomized to either the OSMT program or a control condition of UC. Support persons/family caregivers were invited to participate but not required for survivor eligibility.

The intervention was delivered through five telehealth-enabled (secure cloud videoconferencing) group sessions; three sessions were for survivors-only, one for support persons/family caregivers, and one final booster session that both survivors and support persons/family caregivers attended. Participants with no access to compatible video communications devices or the internet were provided with a loaner tablet enrolled with an unlimited cellular data plan. All participants had technical training prior to the sessions as part of the tri-model technical support model utilized in the study (https://preprints.jmir.org/preprint/26545). The sessions were administered by two trained Wound, Ostomy, and Continence (WOC) nurses and included from 3 - 7 Peer Ostomates. A peer ostomate was a cancer survivor with a long-term ostomy who participated in sessions and occasionally spoke to genderspecific participants outside of the sessions. Peers were screened and carefully interviewed to ensure they were well acclimated to their ostomies and comfortable discussing sensitive issues with 
participants. They were trained in the curriculum and as co-facilitators and buddies. UC participants received standard ostomy care plus written materials on ostomy care and contact for local resources.

Participants in both study arms completed a self-reported survey packet at baseline, and at two and six months post intervention [11]. The 6-month survey packet concluded with an open-ended question, "Many people have shared stories about their lives with an ostomy. Please share with us the greatest challenge you have encountered in having an ostomy." All participants, regardless of randomization assignment, received the open-ended question. The analysis of the open-ended question is presented below.

\section{Data Analysis}

All free text, hand-written responses to the "Greatest Challenge" question were de-identified and transcribed into an Excel spreadsheet. Content analysis with a directed approach was used. The directed content analysis approach allows for the use of an existing theory or relevant, previous research findings as guidance for initial coding $[11,12]$. We used the six conceptual domains from the City of Hope Quality of Life Colorectal (COH-QOL-CRC) model which included higher level domains of Physical, Psychological, Social, and Spiritual Quality of Life; Ostomy-Specific Issues, and Healthcare Issues [6]. Initially, five investigators (MG, VS, NT, MH, RK) reviewed all responses and developed an initial list of Themes within each Domain. Discrepancies were reviewed as a team to then finalize all coding.

Five separate groups of coders (3-4 investigators per group) were formed to identify unique Themes and Codes within the six domains. One separate phone call per coding group was scheduled, and each coding group had at least one researcher with qualitative content analysis experience. The investigative team discussed any issues with the coding scheme during weekly research team videoconference calls; this procedure helped to insure consistency across coding groups. All discrepancies and coding questions were discussed and resolved by the investigative team during weekly team meetings.

Within each of the Quality-of-Life Domains, we report the survey response rates, the number and percentage of coded greatest challenge comments, and the number and percentage distribution of comments by study arm (OSMT vs UC) and by type of ostomy.

We used a Word Cloud analysis to display the frequency of subthemes used by each group (OSMT vs UC) and by type of ostomy (colostomy, ileostomy, and urostomy). This method identifies and displays the most common words or phrases found in a dataset and displays them in a cloud, or diagram where the frequency of a word is indicated by the size of the font used to display it [13]. For this analysis word clouds were generated to visualize the general patterns of the themes mentioned in the greatest challenge comments. Individual datasets composed of the themes and frequencies of each theme were created for (1) the two groups, OSMT vs UC, and then (2) for each ostomy type: Colostomy, lleostomy and Urostomy. As the "Ostomy Care Theme" was the most common theme in both groups and types of ostomies, this theme was omitted in the final Word Clouds to allow differences to become more apparent. The datasets were uploaded into an online word cloud generator "worditout" (http://worditout.com/) to generate a word cloud visualization. Green color and larger font were used to indicate higher frequency. 


\section{Results}

\section{Response Rate and Sample Characteristics}

A total of 216 participants in the randomized study received the 6-month survey (106 in the OSMT Group and 110 in the UC Group). A total of 118 completed the survey question on the greatest challenges, with 55 (47\%) responding from the OSMT Group, and 63 (53\%) responding from the UC Group (Table 1).

Distributions of age and gender were similar across both groups. Over $65 \%$ of the participants from both groups were 12 months or less from their cancer surgery (Table 1). In the OSMT Group, the 55 participants contributed 187 coded comments with an average of 3.4 comments per participant, and the UC Group of 63 contributed 255 coded comments with an average of 4 comments per participant (Table 1).

Distribution of sample characteristics by colostomy, urostomy and ileostomy revealed similar numbers of participants with a colostomy or a urostomy (44 and 45), and 24 with an ileostomy (Table 2). Only 5 participants had more than one stoma, four of them being females. A gender difference occurred in the urostomy group, with $73 \%$ being males. Age analysis indicated a middle-aged population with ileostomies (Mean $=56.5)$ compared to an older group with urostomies (Mean $=73.3)$. Colorectal was the most common type of cancer for those with a colostomy or ileostomy, and urological cancer was the most common for those with a urostomy. Participants with a colostomy contributed 154 comments with an average of 3.5 comments per participant, those with an ileostomy contributed 109 comments with an average of 4.5 comments per participant and those with a urostomy contributed 142 comments with an average of 3.1 comments per respondent.

When examining the distribution of comments on Quality of Life Domains by randomized groups, Ostomy-Specific Issues and the Social Issues were by far the most common challenges experienced by both OSMT and UC groups. The next most common domain for the OSMT group was the Physical Domain, followed by the Psychological and Spiritual Domains. Differences in the UC Group showed the Spiritual Domain next followed by Physical. Healthcare Issues had the fewest comments from both groups.

The distribution of comments on Quality-of-Life Domains by Type of Ostomy showed differences by types of ostomies. For the Colostomy group, the Social Well Being Domain had the highest number of comments followed by Ostomy Specific and Physical Domains. Psychological Domain and Health Care Issues were next with the fewest comments related to Spiritual Well Being. For the lleostomy Group, Ostomy Specific and then Social Well Being had the most comments followed by equal number of comments in Physical Well Being., Spiritual, and Health Care Issues. The Psychological Domain had the least number of comments. For the Urostomy Group, Ostomy Specific Issues had the most comments followed by Social and Spiritual Well Being. Equal number of comments were found for the Physical and Psychological Domains. The fewest comments for the Urostomy Group occurred in Health Care Issues. For participants with more than one stoma, comments were most common in the Social Well Being Domain, followed by Spiritual Well Being. Similar numbers of comments occurred in the Physical, 
Psychological, Ostomy Specific Issues, and Health Care Issues. Differences in the distribution provides information on what content can take priority when guiding specific ostomy patients through the post recovery.

\section{Theme Analysis}

Themes developed within each of the Domain provided additional information on the specific challenges identified by the participants. The Physical Well Being Domain included four themes (Table 3). Comments related to the Bowel Function Theme included problems with gas, noise, odor, constipation, and diarrhea. Comments on the Urinary Function Theme included difficulty regulating, effects of foods, incontinence, and painful urination. Physical Problems included rebuilding strength and increasing activity, as well as decreases in physical activities, pain, strength, and the ability to walk. The Nutrition and Hydration Theme included the need to increase fluid intake, adapting healthy eating, and fears of the effects of specific foods. Examples of quotes for each group are presented in Table 3.

The Psychological Well Being Domain included five themes: Depression, Fear/ Anxiety, Positive Attitude, Negative Attitude, and Feelings of Guilt. Specific quotes are presented in Table 3.

Challenges coded in the Social Well Being Domain were organized under six themes and included Relationship Issues, Sexuality and Intimacy Problems, Going Out in Public, Work/Finances, Positive Support, and Negative Support. Specific comments from each group are presented in Table 3.

The Spiritual Well Being Domain was organized under four themes and included Spiritual Activities, Positive Changes, Negative Changes, and Reason to be Alive. Specific comments are presented in Table 3.

The comments in the Ostomy-Specific Issues Domain were coded into 6 themes: Ostomy Care, Positive and Negative Support, Positive and Negative Education, and Ostomy Reversal. Examples from participants in each group are presented in Table 4.

The Healthcare Issues Domain was created to include challenges related to cancer and non-cancer medical care and treatment. Themes included Post-Operative and Treatment Related Issues, and Cancer. Examples of specific challenges are presented in Table 4.

\section{Word Clouds}

To visualize the content of the greatest challenges identified by the participants in the OSMT Group and the UC Group, datasets composed of the themes and frequencies of each theme were created. Figure 1 provides a Word Cloud comparison of the themes in the OSMT and UC Groups. Post-op and Treatmentrelated issues were common in both groups. Physical Problems, Going out in Public, Fear/Anxiety and Bowel Function were identified more often in the OSMT Group and Going out in Public and Positive Attitude were more frequent in the UC Group. 
Comments were then analyzed based on the type of ostomy using Word Cloud. Post-operative and treatment related issues were most frequent in the Colostomy group, and less so in the lleostomy group, and infrequent in the Urostomy group (Figure 2). The Urostomy group identified the challenge Positive Support most frequently. Bowel Function was dominant in the Colostomy group, less so in the lleostomy group, and not an identified challenge for those with urostomies. Going out in public was a frequent challenge for those with ileostomies, less so for those with colostomies, and infrequent for the Urostomy group. Fear/Anxiety were comments found in the Urostomy group, and in the Colostomy Group, and less in the lleostomy group.

\section{Discussions And Conclusions}

In this study, we were able to compare comments on challenges faced by post-operative ostomy patients participating in a telehealth intervention compared to a group of patients receiving usual care. Responses were analyzed using a framework consisting of six overall domains: Physical Well-Being, Psychological Well-Being, Social Well-Being, Spiritual Well-Being, Ostomy-Specific Issues, and Healthcare Issues. Across all Domains except Physical Well Being, (OSMT 32 comments, UC 32 comments) more comments were submitted by the UC Group. This suggests that the OSMT addressed challenges across domains.

Comments in relation to type of ostomy revealed differences as well. The Social Well Being Domain was the most common area of comments for the Colostomy participants while the Ostomy Specific Domain was the most common for participants with ileostomies and urostomies. The Physical Well Being Domain and the Ostomy Specific Issues were the next most frequent comment areas by those with colostomies while Social Well Being was the second most common area for those with ileostomies and urostomies. These findings illustrate the importance of support and teaching content that addresses the different ostomy groups.

Content in the comments on Physical Well Being Domain included problems with gas and odor, which are especially troublesome because they are socially unacceptable and thus hinder going out in public and interacting with others. Comments also reflected the challenge of rebuilding strength in the face of decreased stamina and difficulty walking. Nutrition and hydration problems included how foods are processed and sometimes cause pain when eaten. Identifying what food to eat and how fast to eat are tasks to be learned. Clearly the creation of an ostomy results in major changes in daily routines for which patients are often barely prepared when discharged from the hospital setting $[4,14]$.

Within the frequently mentioned Social Well Being Domain participants reported that difficulties dealing with the public and attending public events were frequent and revealed an overall concern about being around people in general including relatives, professional staff, friends and strangers. Having an ostomy with unpredictable output causes many patients to avoid being around others. Travel problems included having to explain what an ostomy is when going through airport security as well as concerns about leaks, equipment failures and using public bathrooms. Clothing issues revolved around findings clothes that disguise the pouch and yet are still comfortable and fashionable. Work and financial issues reflected the 
expenses involved in treatment and ostomy maintenance as well as the loss of jobs. Sexuality and intimacy problems are especially important concerns; participants' comments reflect changes in body image and difficulties even for those in long term relationships $[15,16]$. Discussions with peer ostomates on these issues was a large part of the content of the OSMT Sessions

Within the Ostomy-Specific Issues Domain comments reflected problems with various ostomy products and equipment, leaking, skin care, obstructions and hernias and ostomy management issues. While in the hospital, outcome criteria recommended before discharge include assessing and managing skin care, watching for changes in output, selection and care of the pouching system, and identifying resources for additional problems [17]. The environment in the hospital is very different from that experienced when the patient returns home. Problems reflect a needed level of self-care and adjustment that many participants have never faced before and find especially difficulty to carry out $[4,18,19]$. Findings suggest that the telehealth-based content addressed these challenges. Results underscore the published need for health professionals' participation in supporting cancer survivors long term [20-23].

Word Clouds were used to further illustrate differences between the OSMT and UC groups and underscore the differences across various themes. In addition, they illustrate the content needed to provide education and support for ostomy patients and include differences apparent across the three kinds of ostomies.

Our results illustrate the most common challenges that patients with ostomies face, as well as illustrate differences among the three types of ostomies: colostomy, ileostomy, and urostomy. These differences can be used to identify teaching content and support for specific ostomy patients. The greatest challenges identified by participants also validate the content of the OSMT. Specific comments clearly illustrate the daily challenges that impact all aspects of life. The picture that emerges is that of patients with ostomies struggling to adapt to changes that require physical skills in self-care, psychosocial adaptation, dealing with lifelong incontinence, and integrating back into family and social lives. These challenges have been reported in other studies as well [20-22, 24]. Differences in challenges expressed by the different ostomy types also provides a basis for developing education and support services specific to the type of ostomy.

Some limitations are evident in our study. These findings provide information from one time point only. Additional research should include repeated measures to capture when adaptations to challenges are successfully mastered and what challenges persist. This can provide information important in planning cancer survivorship education for this group. Replication with similar groups is recommended, as well as comparing different types of ostomies. Also, our generalizability was limited by participants predominately representing a non-Hispanic white population. Additional studies representing more diverse groups are recommended.

\section{Future Directions for Research}


Our findings point clearly to the need for long term support for the variety of challenges faced by cancer survivors with ostomies. Content related to many of these challenges provides beginning support for the OSMT content and approach. Equipment review and the development of new products and procedures addressed specific problems like leaking and skin problems. Psychosocial support by interacting with peer ostomates provided approaches to problems related to traveling, clothing issues, and social events. Approaches addressed hydration, and physical activity guidelines that can increase general health. In dealing with this array of challenges, support from professional staff as well as peers is vital. Additional testing is needed of the OSMT content in other populations, such as those in rural settings where resources may be scarce or distant.

\section{Declarations}

\section{Funding}

Research reported in this publication was supported through a Patient-Centered Outcomes Research Institute $\AA$ (PCORI $\left.{ }^{\circledR}\right)$ Program Award (CDR 1507-31690). All statements presented in this publication are solely the responsibility of the authors and do not necessarily represent the views of the Patient-Centered Outcomes Research Institute ${ }^{\circledR}\left(\right.$ PCORI $\left.{ }^{\circledR}\right)$, its Board of Governors or Methodology Committee. Funding for this research has been provided in part by The Benjamin \& Mary Siddons Measey Foundation (Miss Mo).

\section{Conflict of interest/Competing interest}

All authors certify that they have no affiliations with or involvement in any organization or entity with any financial interest or non-financial interest in the subject matter or materials discussed in this manuscript.

\section{Availability of data and material}

Not applicable

\section{Code Availability}

Not applicable

\section{Author's contributions}

Conceptualization: Marcia Grant, Virginia Sun, Ruth McCorkle, Robert S. Krouse; Methodology: Marcia Grant, Virginia Sun, Ruth McCorkle, Robert S. Krouse, Elizabeth Ercolano; Formal Analysis: Marcia Grant, Virginia Sun, Ruth McCorkle, Robert S. Krouse; Methodology: Marcia Grant, Virginia Sun, Robert S. Krouse, Elizabeth Ercolano, Nancy J Tallman, Christopher S Wendel, Christie Simons, Julia Mo, Sabreen Raza, Deborah Donahue, Frank Passero, Joshua Hanson, Lyn MacDougall, Jonathan Friedlaender, Pamela Pitcher, Dan Fry, Pete Yonsetto, Mark C. Hornbrook; Funding Acquisition: Marcia Grant, Virginia Sun, Ruth McCorkle, Robert S. Krouse Ronald S Weinstein; Investigation: Marcia Grant, Virginia Sun, Ruth McCorkle, Robert S. Krouse; Project Administration: Sabreen Raza; Resources: Pete Yonsetto, Michael J Holcomb, 
Ronald S Weinstein; Software: : Pete Yonsetto, Michael J Holcomb, Ronald S Weinstein; Supervision: Virginia Sun, Ruth McCorkle, Robert S. Krouse; Validation: Marcia Grant, Virginia Sun, Robert S. Krouse; Visualization: Marcia Grant, Virginia Sun, Ruth McCorkle, Robert S. Krouse; Writing -original draft: Marcia Grant; Writing -review \& editing: Marcia Grant, Virginia Sun, Nancy J. Tallman, Christopher S. Wendel, Ruth McCorkle, Elizabeth Ercolano, Christie Simons, Julia Mo, Sabreen Raza, Deborah Donahue, Frank Passero, Joshua Henson, Lyn MacDougall, Jonathan Friedlaender, Pamela Pitcher, Dan Fry, Pete Yonsetto, Michael J. Holcomb, BS, Mark C. Hornbrook, Ronald S. Weinstein, Robert S. Krouse.

\section{Ethics approval}

Approval was obtained from the Institutional Review Board at the University of Pennsylvania, City of Hope and Yale University.

\section{Consent to participate}

Informed consent was obtained from all individual participants included in the study.

\section{Consent to Publish}

Patients signed informed consent regarding publishing their data.

\section{References}

1. Bulkley JE, McMullen CK, Grant M, Wendel C, Hornbrook MC, Krouse RS (2018) Ongoing ostomy selfcare challenges of long-term rectal cancer survivors. Support Care Cancer 26(11):3933-3939

2. Hubbard G, Taylor C, Beeken B, Campbell A, Gracey J, Grimmett C et al (2017) Research priorities about stoma-related quality of life from the perspective of people with a stoma: A pilot survey. Health Expect 20(6):1421-1427

3. Mols F, Lemmens V, Bosscha K, van den Broek W, Thong MS (2014) Living with the physical and mental consequences of an ostomy: a study among 1-10-year rectal cancer survivors from the population-based PROFILES registry. Psychooncology 23(9):998-1004

4. Torquato Lopes AP, Decesaro M (2014) The adjustments experienced by persons with an ostomy: an integrative review of the literature. Ostomy Wound Manage 60(10):34-42

5. United Ostomy Association of America. Living with an ostomyMay 19, 2020. Available from:

6. McMullen CK, Hornbrook MC, Grant M, Baldwin CM, Wendel CS, Mohler MJ et al (2008) The greatest challenges reported by long-term colorectal cancer survivors with stomas. J Support Oncol 6(4):175182

7. Sun V, Grant M, McMullen CK, Altschuler A, Mohler MJ, Hornbrook MC et al (2013) Surviving colorectal cancer: long-term, persistent ostomy-specific concerns and adaptations. J Wound Ostomy Continence Nurs 40(1):61-72 
8. Grant M, McCorkle R, Hornbrook MC, Wendel CS, Krouse R (2013) Development of a chronic care ostomy self-management program. J Cancer Educ 28(1):70-78

9. Krouse RS, Grant M, McCorkle R, Wendel CS, Cobb MD, Tallman NJ et al (2016) A chronic care ostomy self-management program for cancer survivors. Psychooncology 25(5):574-581

10. Sun V, Ercolano E, McCorkle R, Grant M, Wendel CS, Tallman NJ et al (2018) Ostomy telehealth for cancer survivors: Design of the Ostomy Self-management Training (OSMT) randomized trial. Contemp Clin Trials 64:167-172

11. Grant M, Ferrell B, Dean G, Uman G, Chu D, Krouse R (2004) Revision and psychometric testing of the City of Hope Quality of Life-Ostomy Questionnaire. Qual Life Res 13(8):1445-1457

12. Hsieh HF, Shannon SE (2005) Three approaches to qualitative content analysis. Qual Health Res 15(9):1277-1288

13. McNaught C, Lan P (2010) Using Wordle as supplementary research tool. The Qualitative Report 15(3):630-643

14. Goldblatt J, Buxey K, Paul E, Foot-Connolly R, Leech T, Bell S (2018) Study on the time taken for patients to achieve the ability to self-care their new stoma. ANZ J Surg 88(6):E503-E506

15. Ramirez M, Altschuler A, McMullen C, Grant M, Hornbrook M, Krouse R (2014) "I didn't feel like I was a person anymore": realigning full adult personhood after ostomy surgery. Med Anthropol Q 28(2):242-259

16. Ozturk O, Yalçin BM, Unal M, Yildirim K, Ozlem N (2015) Sexual Dysfunction among Patients having undergone Colostomy and its Relationship with Self-Esteem. Journal of Family Medicine Community Health 2(1):1028

17. Colwell JC, Kupsick PT, McNichol LL. Outcome Criteria for Discharging the Patient With a New Ostomy From Home Health Care: A WOCN Society Consensus Conference. J Wound Ostomy Continence Nurs. 2016;43(3):269 - 73

18. Claessens I, Probert R, Tielemans C, Steen A, Nilsson C, Andersen BD et al (2015) The Ostomy Life Study: the everyday challenges faced by people living with a stoma in a snapshot. Gastrointestinal Nursing 13(5):18-25

19. Taylor C (2013) Reach for recovery: evaluating a pilot study of a colorectal cancer survivorship programme. Eur J Oncol Nurs 17(2):131-137

20. Nasvall P, Dahlstrand U, Lowenmark T, Rutegard J, Gunnarsson U, Strigard K (2017) Quality of life in patients with a permanent stoma after rectal cancer surgery. Qual Life Res 26(1):55-64

21. McMullen CK, Bulkley JE, Altschuler A, Wendel CS, Grant M, Hornbrook MC et al (2016) Greatest Challenges of Rectal Cancer Survivors: Results of a Population-Based Survey. Dis Colon Rectum 59(11):1019-1027

22. Grant M, McMullen CK, Altschuler A, Mohler MJ, Hornbrook MC, Herrinton LJ et al (2011) Gender differences in quality of life among long-term colorectal cancer survivors with ostomies. Oncol Nurs Forum 38(5):587-596 
23. Wiltink LM, White K, King MT, Rutherford C (2020) Systematic review of clinical practice guidelines for colorectal and anal cancer: the extent of recommendations for managing long-term symptoms and functional impairments. Support Care Cancer 28(6):2523-2532

24. Jansen F, van Uden-Kraan CF, Braakman JA, van Keizerswaard PM, Witte BI, Verdonck-de Leeuw IM (2015) A mixed-method study on the generic and ostomy-specific quality of life of cancer and noncancer ostomy patients. Support Care Cancer 23(6):1689-1697

\section{Tables}

Table 1

Sample Characteristics and Comments by Randomized Groups $(\mathrm{N}=118)$

\begin{tabular}{|c|c|c|}
\hline Characteristic & $\begin{array}{l}\text { OSMT } \\
N=55(47 \%)\end{array}$ & $\begin{array}{l}\text { Usual Care } \\
N=63(53 \%)\end{array}$ \\
\hline Mean age, years (SD) & 61.4 (12.0.) & $67.6(12.9)$ \\
\hline $\begin{array}{l}\text { Gender, N (\%) } \\
\text { Male } \\
\text { Female }\end{array}$ & $\begin{array}{l}31(56.4 \%) \\
24(43.6 \%)\end{array}$ & $\begin{array}{l}34(54.0 \%) \\
29(46.0 \%)\end{array}$ \\
\hline Non-Hispanic White, N (\%) & $45(81.8 \%)$ & $54(85.7 \%)$ \\
\hline $\begin{array}{l}\text { Type of Ostomy, N (\%) } \\
\text { Colostomy } \\
\text { lleostomy } \\
\text { Urostomy } \\
\text { More than one stoma }\end{array}$ & $\begin{array}{l}24(43.6 \%) \\
15(27.3 \%) \\
15(27.3 \%) \\
1(1.8 \%)\end{array}$ & $\begin{array}{l}20(31.7 \%) \\
9(14.3 \%) \\
30(47.6 \%) \\
4(6.3 \%)\end{array}$ \\
\hline $\begin{array}{l}\text { Months since surgery, } \mathrm{N}(\%) \\
\leq 12 \text { months } \\
>12 \text { months } \\
\text { Unknown }\end{array}$ & $\begin{array}{l}40(72.7 \%) \\
15(27.3 \%) \\
0\end{array}$ & $\begin{array}{l}41(65.1 \%) \\
19(30.2 \%) \\
3(4.8 \%)\end{array}$ \\
\hline Coded comments, 422 (100\%) & $187(44.3 \%)$ & $235(55.7 \%)$ \\
\hline
\end{tabular}


Table 2

Sample Characteristics and Comments by Type of Ostomy $(N=118)$

\begin{tabular}{|c|c|c|c|c|}
\hline Characteristics & $\begin{array}{l}\text { Colostomy } \\
\mathrm{N}=44 \\
(37 \%)\end{array}$ & $\begin{array}{l}\text { lleostomy } \\
\mathrm{N}=24 \\
(20 \%)\end{array}$ & $\begin{array}{l}\text { Urostomy } \\
\mathrm{N}=45 \\
(38 \%)\end{array}$ & $\begin{array}{l}\text { More Than One Stoma N = } \\
5(4 \%)\end{array}$ \\
\hline $\begin{array}{l}\text { Gender N (\%) } \\
\mathrm{M} \\
\mathrm{F}\end{array}$ & $\begin{array}{l}18(40.9 \%) \\
26(59.1 \%)\end{array}$ & $\begin{array}{l}13 \\
(54.2 \%) \\
11 \\
(45.8 \%)\end{array}$ & $\begin{array}{l}33(73.3) \\
12(26.7)\end{array}$ & $\begin{array}{l}1(20 \%) \\
4(80 \%)\end{array}$ \\
\hline Mean age, years (SD) & $\begin{array}{l}60.9 \\
(10.8)\end{array}$ & $\begin{array}{l}56.5 \\
(14.6)\end{array}$ & $73.3(8.2)$ & $60.2(11.9)$ \\
\hline $\begin{array}{l}\text { Type of Cancer N (\%) } \\
\text { Colorectal } \\
\text { Urological } \\
\text { Gynecological } \\
\text { Other } \\
\text { Unknown }\end{array}$ & $\begin{array}{l}35(79.5 \%) \\
0 \\
6(13.6 \%) \\
1(2.3 \%) \\
2(4.5 \%)\end{array}$ & $\begin{array}{l}19 \\
(79.0 \%) \\
2(8.3 \%) \\
2(8.3 \%) \\
1(4.2 \%) \\
0\end{array}$ & $\begin{array}{l}1(2.2 \%) \\
41(91.1) \\
2(4.4 \%) \\
0 \\
1(2.2 \%)\end{array}$ & $\begin{array}{l}2(40 \%) \\
0 \\
3(60 \%) \\
0 \\
0\end{array}$ \\
\hline $\begin{array}{l}\text { Time since Ostomy Surgery } \\
\text { (months) } \\
\leq 12 \text { months } \\
>12 \text { months } \\
\text { Unknown }\end{array}$ & $\begin{array}{l}31(70.5 \%) \\
13 \\
(29.15 \%) \\
0\end{array}$ & $\begin{array}{l}21 \\
(87.5 \%) \\
2(8.3 \%) \\
1(4.2 \%)\end{array}$ & $\begin{array}{l}26 \\
(57.8 \%) \\
17 \\
(37.8 \%) \\
2(4.4 \%)\end{array}$ & $\begin{array}{l}3(60 \%) \\
2(40 \%) \\
0\end{array}$ \\
\hline Coded comments, 422 (100\%) & $\begin{array}{l}154 \\
(36.5 \%)\end{array}$ & $\begin{array}{l}109 \\
(25.8 \%)\end{array}$ & $\begin{array}{l}142 \\
(33.7)\end{array}$ & $17(4.0 \%)$ \\
\hline
\end{tabular}


Table 3

Distribution and Examples of Physical, Psychological, Social and spiritual Well-Being Challenges

\begin{tabular}{|c|c|c|c|}
\hline Domains & Themes & Intervention Group & Usual Care Group \\
\hline \multirow{5}{*}{$\begin{array}{l}\text { Physical Well } \\
\text { Being } \\
64(15.2 \%)\end{array}$} & & 32 & 32 \\
\hline & Bowel Function & Painful constipation & $\begin{array}{l}\text { (challenges with) controlling } \\
\text { diarrhea }\end{array}$ \\
\hline & Urinary Function & $\begin{array}{l}\text { Making sure I empty } \\
\text { my ostomy bag every } \\
\text { two hours. }\end{array}$ & $\begin{array}{l}\text { Errant-running around now has to } \\
\text { be planned around available } \\
\text { restrooms }\end{array}$ \\
\hline & Physical Problems & $\begin{array}{l}\text { Many physical } \\
\text { activities are out of } \\
\text { bounds for me }\end{array}$ & I still cannot walk and climb stairs \\
\hline & Nutrition/Hydration & $\begin{array}{l}\text { I was in constant pain } \\
\text { anytime I would eat } \\
\text { and process the food } \\
\text { so I was scared to eat. }\end{array}$ & $\begin{array}{l}\text { Sometimes my bag is full before } \\
\text { l've even finished eating a meal. }\end{array}$ \\
\hline \multirow{6}{*}{$\begin{array}{l}\text { Psychological } \\
\text { Well Being } \\
51(12.1 \%)\end{array}$} & & 21 & 30 \\
\hline & Depression & $\begin{array}{l}\text { Emotional, down at } \\
\text { (times), frustrated, } \\
\text { discouraged. }\end{array}$ & I feel so lonely and left out a lot. \\
\hline & Fear/Anxiety & $\begin{array}{l}\text { The ostomy is my } \\
\text { nightmare }\end{array}$ & $\begin{array}{l}\text { I barely go out because I'm scared } \\
\text { of accidents. }\end{array}$ \\
\hline & Positive Attitude & $\begin{array}{l}\text { I have overcome a lot } \\
\text { this year which has } \\
\text { made me a stronger } \\
\text { person.... }\end{array}$ & $\begin{array}{l}\text { As years go by, I finally accepted } \\
\text { that I will have this for the rest of } \\
\text { my life. }\end{array}$ \\
\hline & Negative Attitude & $\begin{array}{l}\text { This is the worst thing } \\
\text { that has happened to } \\
\text { me. }\end{array}$ & It is disgusting and makes me gag. \\
\hline & $\begin{array}{l}\text { Guilty, Feelings of } \\
\text { Guilt }\end{array}$ & $\begin{array}{l}\text { Accepting that I } \\
\text { needed other people to } \\
\text { help me with my basic } \\
\text { needs. }\end{array}$ & $\begin{array}{l}\text { Having to depend on everyone for } \\
\text { help. }\end{array}$ \\
\hline $\begin{array}{l}\text { Social Well } \\
\text { Being } \\
93(22.0 \%)\end{array}$ & & 44 & 49 \\
\hline
\end{tabular}




\begin{tabular}{|c|c|c|c|}
\hline \multirow[t]{7}{*}{ Domains } & Themes & Intervention Group & Usual Care Group \\
\hline & Relationship Issues & $\begin{array}{l}\text { Going out or having } \\
\text { friends over. My stoma } \\
\text { will make noise or } \\
\text { smell and I have no } \\
\text { control over that }\end{array}$ & $\begin{array}{l}\text { Being able to go out socially with } \\
\text { friends. Constant bathroom visits } \\
\text { and possible bag leaks makes me } \\
\text { not want to go out. }\end{array}$ \\
\hline & $\begin{array}{l}\text { Sex/sexuality and } \\
\text { intimacy problems }\end{array}$ & $\begin{array}{l}\text { ED which has caused } \\
\text { a great reduction in } \\
\text { intimacy }\end{array}$ & $\begin{array}{l}\text { It's been } 9 \text { months since surgery, } \\
\text { and I have not yet been intimate } \\
\text { with my husband of almost } 30 \\
\text { years. Hugging and kissing is it for } \\
\text { us right now. }\end{array}$ \\
\hline & Going out in Public & $\begin{array}{l}\text { My family is } \\
\text { accustomed to this, } \\
\text { but I am extremely } \\
\text { reluctant to be around } \\
\text { other people }\end{array}$ & $\begin{array}{l}\text { I barely go out because I am } \\
\text { scared of accidents }\end{array}$ \\
\hline & Work/Finances & $\begin{array}{l}\text { Big time loss of wages } \\
\text { caused forever big } \\
\text { bills on us all }\end{array}$ & $\begin{array}{l}\text { Not being able to work is the } \\
\text { hardest. Financial affairs are } \\
\text { difficult? Husband has to work } \\
\text { double time... We need the } \\
\text { insurance. }\end{array}$ \\
\hline & Positive Support & $\begin{array}{l}\text { Closer bond with my } \\
\text { wife. She is an } \\
\text { excellent "caring" } \\
\text { caregiver }\end{array}$ & $\begin{array}{l}\text { Excellent care and support of } \\
\text { many health professionals, family, } \\
\text { and friends }\end{array}$ \\
\hline & Negative Support & $\begin{array}{l}\text { Even when I went to } \\
\text { the ER, only one staff } \\
\text { member knew what to } \\
\text { do. }\end{array}$ & $\begin{array}{l}\text { My wife does not participate in my } \\
\text { care and she would not be able to } \\
\text { care for me in the future }\end{array}$ \\
\hline \multirow{5}{*}{$\begin{array}{l}\text { Spiritual Well } \\
\text { Being } \\
57(13.5 \%)\end{array}$} & & 21 & 36 \\
\hline & Spiritual Activities & $\begin{array}{l}\text { I am not a happy man } \\
\text { but alive by the grace } \\
\text { of almighty God and } \\
\text { his mercies }\end{array}$ & $\begin{array}{l}\text { Still in the fight. Please pray for me } \\
\text { and my family }\end{array}$ \\
\hline & Positive Changes & $\begin{array}{l}\text { I am grateful for all the } \\
\text { learnings through the } \\
\text { entire experience }\end{array}$ & My surgery saved my life \\
\hline & Negative Changes & $\begin{array}{l}\text { The ostomy is my } \\
\text { nightmare }\end{array}$ & $\begin{array}{l}\text { I hate it and feel sorry for anyone } \\
\text { who has to deal with this }\end{array}$ \\
\hline & Reason to be Alive & $\begin{array}{l}\text { I beat cancer and got } \\
\text { rid of ulcerative colitis. } \\
\text { It has given me a } \\
\text { better quality of life }\end{array}$ & $\begin{array}{l}\text { Actually, my life improved after the } \\
\text { surgery. My life is now normal } \\
\text { again }\end{array}$ \\
\hline
\end{tabular}


Table 4

Examples of Ostomy Specific Issues and Healthcare Issues

\begin{tabular}{|c|c|c|c|}
\hline Domains & Themes & Intervention Group & Usual Care Group \\
\hline \multirow{7}{*}{$\begin{array}{l}\text { Ostomy } \\
\text { Specific } \\
\text { Issues } \\
115 \\
(27.3 \%)\end{array}$} & & 51 & 64 \\
\hline & $\begin{array}{l}\text { Ostomy } \\
\text { Care }\end{array}$ & $\begin{array}{l}\text { Dealing with the chemo and } \\
\text { the ostomy have been the } \\
\text { biggest challenges. }\end{array}$ & $\begin{array}{l}\text { Biggest obstacle is caring for the } \\
\text { ostomy } 24 \text { hours a day. }\end{array}$ \\
\hline & $\begin{array}{l}\text { Positive } \\
\text { Support }\end{array}$ & $\begin{array}{l}\text { I did receive a lot of help from } \\
\text { family and medical } \\
\text { professionals. }\end{array}$ & $\begin{array}{l}\text { Thanks to the care I got from } \\
\text { (medical professionals), my care was } \\
\text { easy. }\end{array}$ \\
\hline & $\begin{array}{l}\text { Negative } \\
\text { Support }\end{array}$ & $\begin{array}{l}\text { (My greatest challenge was) } \\
\text { when a medical professional } \\
\text { was not compassionate. }\end{array}$ & $\begin{array}{l}\text { The home nursing care gave me little } \\
\text { help with management or correction } \\
\text { of problems. }\end{array}$ \\
\hline & $\begin{array}{l}\text { Positive } \\
\text { Education }\end{array}$ & $\begin{array}{l}\text { Thanks to the (medical } \\
\text { professionals) I learned to take } \\
\text { care of my ostomy. }\end{array}$ & $\begin{array}{l}\text { The care and education I received at } \\
\text { made everything very easy. The } \\
\text { doctors, nurses, and volunteers were } \\
\text { all wonderful... }\end{array}$ \\
\hline & $\begin{array}{l}\text { Negative } \\
\text { Education }\end{array}$ & $\begin{array}{l}\text { (I had painful constipation) It } \\
\text { would have been helpful to be } \\
\text { told ahead of time that this } \\
\text { could be a reality. }\end{array}$ & $\begin{array}{l}\text { I keep seeing information about } \\
\text { irrigation and I have never been told } \\
\text { anything about whether I should be } \\
\text { doing it. }\end{array}$ \\
\hline & $\begin{array}{l}\text { Ostomy } \\
\text { Reversal }\end{array}$ & $\begin{array}{l}\text { My ileostomy was successfully } \\
\text { reversed. }\end{array}$ & $\begin{array}{l}\text { I am lucky my ostomy is temporary } \\
\text { and I will have reversal surgery. }\end{array}$ \\
\hline \multirow{3}{*}{$\begin{array}{l}\text { Healthcare } \\
\text { Issues } \\
42(10.0 \%)\end{array}$} & & 18 & 24 \\
\hline & $\begin{array}{l}\text { Post- } \\
\text { Operative } \\
\text { and } \\
\text { Treatment } \\
\text { Related } \\
\text { Issues }\end{array}$ & $\begin{array}{l}\text { Having to rebuild my strength } \\
\text { after numerous } \\
\text { hospitalizations }\end{array}$ & Nerve damage due to chemotherapy \\
\hline & Cancer & Cancer is a big scary thing. & Cancer Sucks!! \\
\hline
\end{tabular}

\section{Figures}




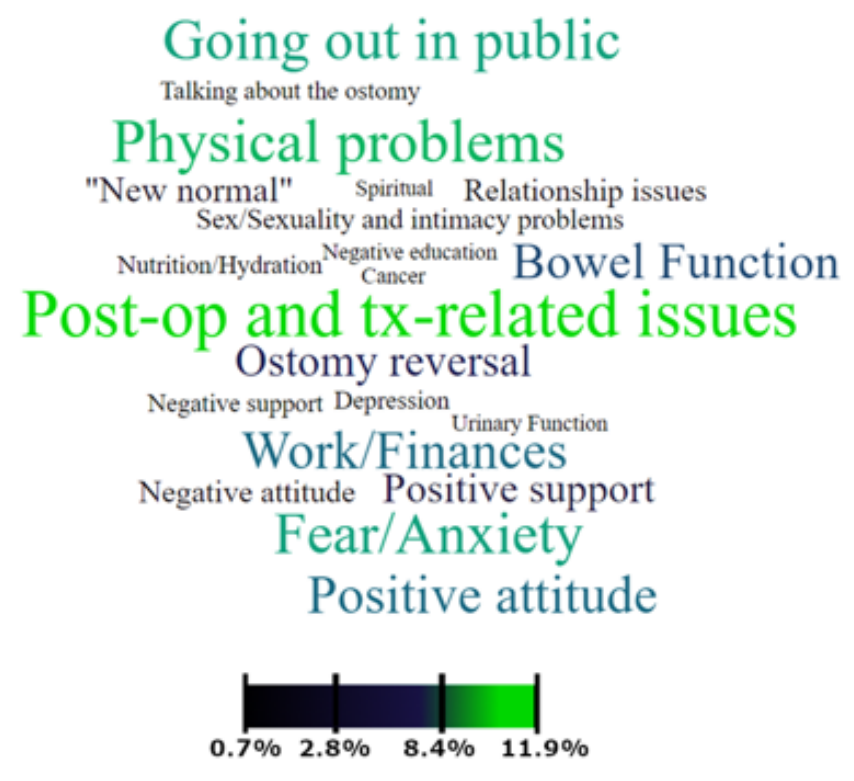

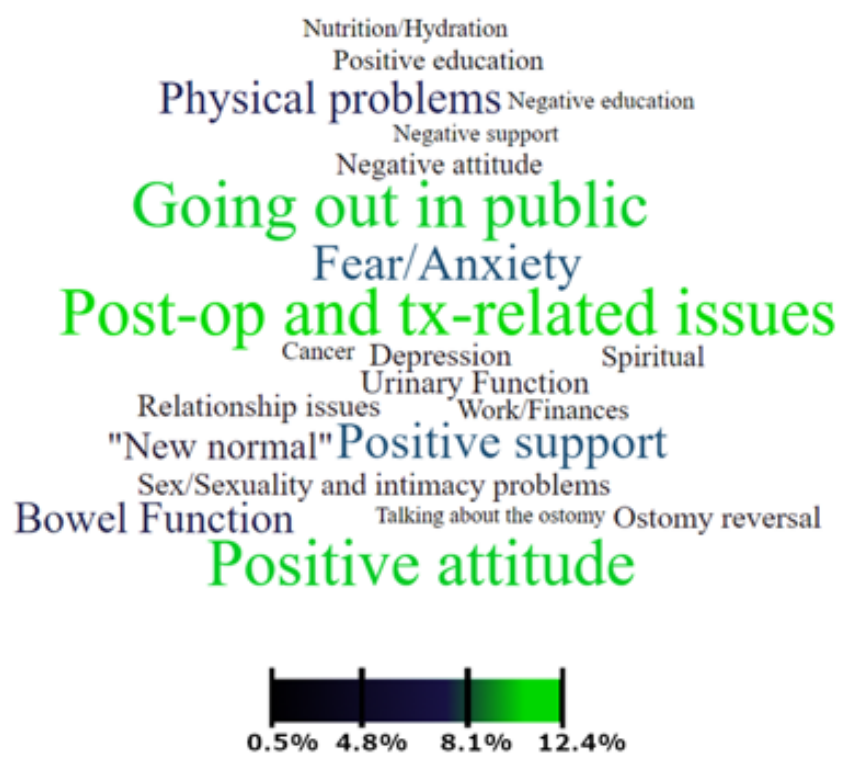

Figure 1

Word Cloud for OSMT and UC: (A) OSMT, (B) UC.

(A)

(B)

(C)

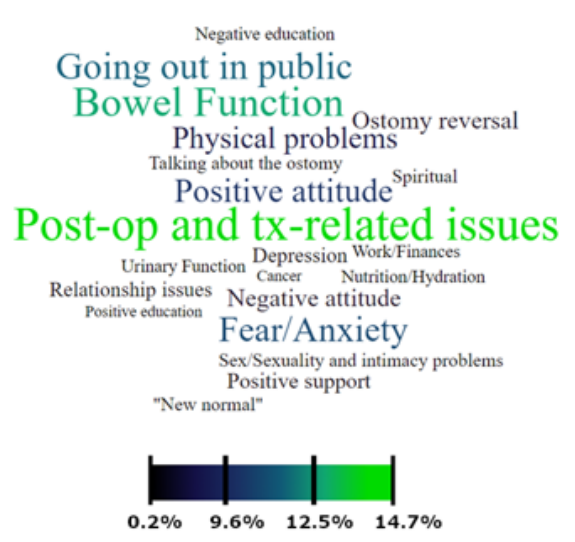

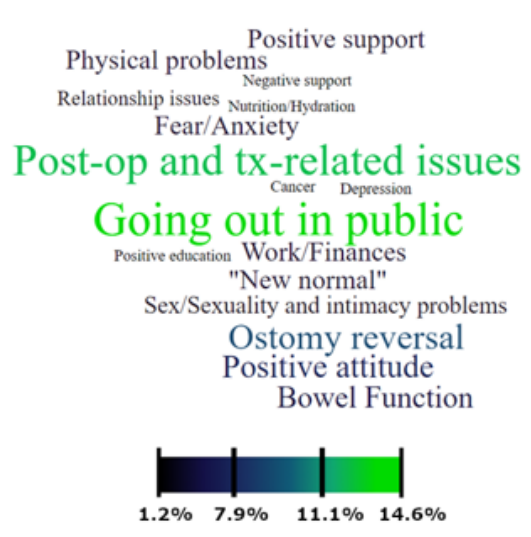

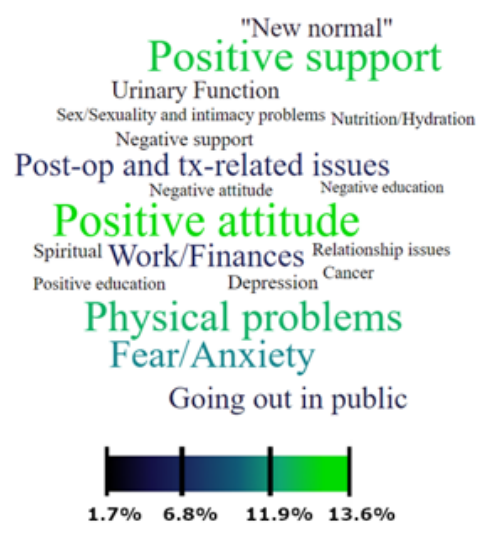

\section{Figure 2}

Word Cloud for Type of Ostomy: (A) Colostomy, (B) Ileostomy, (C) Urostomy. 